\title{
MODEL HUBUNGAN BEBAN KERJA, KOMPENSASI DAN PENGEMBANGAN KARIR TERHADAP LOYALITAS KARYAWAN PT. $A B C$
}

\author{
* Agung Solihin ${ }^{1}$ \\ ${ }^{1}$ Fakultas Bisnis dan Ilmu Sosial, Program Studi Manajemen, Universitas Dian Nusantara, Jakarta, Indonesia
}

*Email Korespondensi:

agung.solihin@undira.ac.id

\section{ARTIKEL INFORMASI}

Diterima:

3 March 2021

Direvisi:

15 April 2021

Dipublikasi:

16 Mei 2021

\begin{abstract}
ABSTRAK
Loyalitas karyawan merupakan kesetiaan karyawan untuk memberikan kontribusi melakukan akivitas pekerjaan terhadap perusahaan karyawan mengharapkan imbalan atas kesetiaan yang sudah diberikan demi kemajuan organiasasi. Tujuan dari penelitian ini untuk mengetahui model hubungan beban kerja, kompensasi dan Pengembangan karir terhadap loyalitas karyawan. Populasi dalam penelitian ini adalah karyawan PT. XYZ menggunakan analisis regresi linier berganda. Hasil penelitian dan hipotesis menunjukkan bahwa secara simultan, Beban Kerja, Kompensasi dan Pengemebangan Karir berpengaruh terhadap Loyalitas Karyawan.
\end{abstract}

Kata Kunci: Beban Kerja, Kompensasi, Pengembangan Karir, Loyalitas Karyawan

\section{PENDAHULUAN}

Sebagian besar perusahaan hari ini masih menerapkan work from home seiring dengan masih diberlakukannya Pembatasan Sosial Berskala Besar (PSBB). Memang benar, perusahaan tak hanya dituntut untuk membesarkan atau menjaga basis pelanggan mereka. Talenta di dalam perusahaan juga harus dijaga. Dengan bantuan teknologi, diharapkan sistem pengembangan karyawan dapat berjalan dengan baik dan menjaga loyalitas mereka. (kadinjateng.com). Sumber Daya Manusia merupakan komponen utama dalam mewujudkan visi dan misi suatu organisasi, Selain itu SDM sebagai asset utama dalam menjalankan aktifitas perusahaan. Mereka memiliki tujuan, keinginan, fikiran, status, perasaan untuk memenuhi kebutuhannya. Mereka juga mempunyai latar belakang pendidikan, jenis kelamin dan usia yang heterogen dibawa kedalam organisasi sehingga mereka tidak seperti uang, material dan teknologi yang memiliki sifat pasif dan dapat dikuasai sepenuhnya dalam mencapai tujuan perusahaan.

Menurut Tommy dkk., (2010) Loyalitas dapat dikatakan sebagai kesetiaan seseorang terhadap suatu hal yang bukan hanya berupa kesetiaan fisik semata, namun lebih pada kesetiaan non fisik seperti pikiran dan perhatian. Loyalitas merupakan aspek penting bagi setiap perusahaan, loyalitas karyawan yang tinggi akan mempengaruhi pencapaian tujuan perusahaan. Dan loyalitas yang sangat rendah akan mempengaruhi kegagalan dalam mencapai tujuan perusahaan yang diharapkan. Pada dasarnya loyalitas 
karyawan yang tinggi menjadi harapan yang paling utama bagi setiap perusahaan. Menurut Gilbert (dalam Kurniawati, 2011) agar karyawan mempunyai loyalitas yang tinggi pada perusahaan dilakukan dengan cara mengambil perhatian, memuji kemajuan, perpindahan, kenaikan upah, promosi jabatan, memberitahukan kepada karyawan tentang apa yang terjadi pada perusahaan, membiarkannya mengerti bagaimana bekerja dengan baik serta mau mendengarkan keluhan para karyawan.

Loyalitas adalah keinginan untuk memproteksi dan menyelamatkan wajah bagi orang lain. Fletcher merumuskan loyalitas sebagai kesetiaan kepada seseorang dengan tidak meninggalkan, membelot atau tidak mengkhianati yang lain pada waktu diperlukan. Banyak faktor yang menjadikan seorang karyawan menjadi loyal, diantaranya kepuasan kerja, kompensasi atau insentif, komunikasi yang efektif, motivasi yang diberikan oleh perusahaan, tempat kerja yang nyaman, serta hubungan dengan karyawan lain. Saat ini pengertian loyalitas karyawan bukan lagi sekadar merujuk pada kemampuan karyawan menjalankan tugas-tugas serta kewajibannya yang sesuai dengan job description, melainkan berbuat seoptimal mungkin untuk menghasilkan yang terbaik bagi perusahaan tersebut.

Adapun beberapa penyebab keluarnya karyawan antara lain beban kerja yang berlebih dari jam normal atau over time, selain itu tugas-tugas yang dikerjakan banyak yang tidak sesuai dengan jobdesk yang diberikan pada saat rekrutmen. Masalah lainnya adanya Additional Task diluar pekerjaan inti, yang seharusnya pekerjaan dapat dikerjakan beberapa orang namun pekerjaan tersebut dikerjakan hanya satu orang, kurangnya coaching atau arahan untuk pembagian tugas masing-masing karyawan menyebabkan stres pada sebagian karyawan menjadi meningkat dikarenakan pekerjaan tersebut harus diselesaikan dalam waktu yang ditentukan. Faktor-faktor penyebab lainnya adalah tingkat kompensasi atau upah kerja yang masih belum sesuai tugas yang diberikan yang menyebabkan produktivitas kerja menurun, nilai kompensasi dapat dikatakan masih belum sesuai dengan tingkat beban kerja yang diperoleh karyawan. Selain itu, Setiap karyawan melakukan lembur secara normal keseringan tidak di bayar kecuali tanggal merah. Beberapa hal tersebut yang menyebabkan karyawan tidak loyal dan bersikap apatis tidak mau membantu karyawan lainnya karena menganggap bukan tugasnya dan hanya membuang waktu.

Banyak karyawan yang sudah bekerja puluhan tahun namun level jabatan masih sebagai staff biasa, sedangkan pegawai yang baru di rekrut dengan bermodalkan ijazah Strata 1 sudah dapat menduduki jabatan level Store Manager. Dan prasyarat dalam pengembangan karir masih berpedoman dengan performance aprisal. Inilah kesenjangan yang terjadi dalam pengembangan karir yang menyebabkan banyaknya karyawan yang tidak loyal terhadap perusahaan. Selanjutnya kompensasi yang diperoleh pegawai sangat mempengaruhi penurunan loyalitas karyawan dikarenakan karyawan melakukan pernyataan bahwa kompensasi yang didapatkan masih dikatakan belum baik, dikarenakan tidak ada kesesuaian banyaknya pekerjaan dengan kompensasi yang diperoleh. Karyawan memerlukan tunjangan tambahan lain untuk meningkatkan loyalitas tersebut.

Dari fenomena yang diketahui maka dapat diperoleh kesimpulan bahwa dalam membentuk loyalitas karyawan yang baik adalah perlu adanya pemberian beban kerja yang sesuai dengan spesifikasi jabatan yang karyawan terima, diharapkan pekerjaan tidak terlalu berlebihan, dan menyesuaikan kapasitas waktu dan kinerja karyawan. Selain itu, loyalitas dapat diwujudkan dengan pemberian kompensasi yang baik agar karyawan mendapatkan kesejahteraan dan motivasi dalam meningkatkan produktivitas sehingga karyawan memberikan kontribusi dalam mencapai tujuan perusahaan. Dan pengembangan karir perlu ditingkatkan, perusahaan membentuk peluang-peluang karir bukan hanya dengan memperoleh prasyarat kompetensi tapi juga pengalaman kerja karyawan dalam membantu meningkatkan efektivitas dan efisiensi perusahaan dalam memelihara SDM yang baik sehingga loyalitas karyawan dapat diciptakan untuk menjaga kestabilan organisasi.

\section{KAJIAN PUSTAKA}

\section{Beban Kerja \\ Definisi Beban Kerja}

Beban kerja adalah suatu proses analisa terhadap waktu yang digunakan oleh seseorang atau sekelompok orang dalam menyelesaikan tugas-tugas suatu pekerjaan (jabatan) atau kelompok jabatan (unit kerja) yang dilaksanakan dalam keadaan/kondisi normal" (Adil Kurnia 2010). Menurut Adil Kurnia (2010), analisa beban kerja adalah proses untuk menetapkan jumlah jam kerja orang yang digunakan atau dibutuhkan untuk merampungkan suatu pekerjaan dalam waktu tertentu, atau dengan kata lain analisis beban kerjabertujuan untuk menentukan berapa jumlah personalia dan berapa jumlah tanggung jawab atau beban kerja yang tepat dilimpahkan 
kepada seorang petugas. Menurut Adil Kurnia (2010), analisis beban kerja adalah mengidentifikasi baik jumlah karyawan maupun kwalifikasi karyawan yang diperlukan untuk mencapai tujuan organisasi. Menurut Adil Kurnia (2010), pengertian beban kerja adalah sekumpulan atau sejumlah kegiatan yang harus diselesaikan oleh suatu unit organisasi atau pemegang jabatan dalam jangka waktu tertentu.

Menurut Danang Sunyoto (2012:64), beban kerja adalah pekerjaan yang terlalu banyak dapat menyebabkan ketegangan dalam diri seseorang sehingga menimbulkan stress. Hal ini bisa disebabkan oleh tingkat keahlian yang dituntut terlalu tinggi, kecepatan kerja mungkin terlalu tinggi, volume kerja mungkin terlalu banyak dan sebagainya. Berdasarkan teori-teori yang diperoleh dari pendapat ahli di atas, kesimpulannya adalah beban kerja yaitu penentuan jumlah jam kerja pegawai untuk menyelsaikan pekerjaan dan beban kerja sebagai pekerjaan yang terlalu bayak yang menyebabkan ketegangan atau stres dalam bekerja.

\section{Kompensasi \\ Definisi Kompensasi}

Gaol (2014:310), Kompensasi merupakan hal yang diterima oleh pegawai, baik berupa uang atau bukan uang sebagai balas jasa yang diberikan atas kontribusi pegawai kepada organisasi. Menurut Hasibuan (2013:117) Kompensasi adalah semua pendapatan yang berbentuk uang, barang lngsung ataupun tidak langsung yang diterima oleh karyawan sebagai imbalan atas yang diberikan kepada perusahaan. Menurut Sastrohadiwiryo dalam bukunya Yuniarsih (2011:125) Kompensasi adalah imbalan jasa atau balas jasa yang diberikan oleh perusahaan kepada para tenaga kerja, karena para tenaga kerja tersebut telah memberikan sumbangan tenaga dan pikiran demi kemajuan perusahaan guna mencapai tujuan yang ditetapkan.Para pemberi kerja harus agak kompetitif dengan beberapa jenis kompensasi untuk menarik dan mempertahankan karyawan yang kompeten.

Dessler (2015:417), kompensasi karyawan (employee compensation) meliputi semua bentuk bayaran yang diberikan kepada karyawan dan timbul dari hubungan kerja mereka. Kompensasi karyawan memiliki dua komponen utama, yaitu pembayaran finansial langsung atau direct financial payments (upah, gaji, insentif, komisi dan bonus) dan pembayaran finansial tidak langsung atau indirect financial payments (tunjangan finasial seperti ansuransi dan liburan yang dibayar oleh pemberi kerja). Berdasarkan teori-teori dari masing - masing pendapat ahli, bahwa dapat disimpullkan kompensasi merupakan balas jasa yang diberikan atas kontribusi karyawan terhadap organisasi, selain itu kompensasi memiliki komponen direct financial maupun indirect financial, direct financial berupa upah,gaji, insentif dan bonus danindirect financial berupa Tunjangan, asuransi dll.

\section{Pengembangan Karir \\ Definisi Pengembangan Karir}

Collin dalam Kaswan (2014:14) yang menyatakan bahwa "individual work histories, sequences of and patterns in occupations and work positions and upward progress in an occupation or in life generally." Intinya adalah karir merupakan riwayat pekerjaan seseorang, serangkaian dan pola dalam pekerjaan dan posisi pekerjaan, serta kemajuan dalam pekerjaan atau dalam kehidupan. Sedangkan Ivancevich (2013: 435) menyatakan, karir adalah pola pengalaman yang terkait dengan pekerjaan (misalnya: posisi pekerjaan, kewajiban pekerjaan, keputusan dan interpretasi subjektif mengenai peristiwa yang berkaitan dengan pekerjaan) dan aktivitas sepanjang rentang masa hidup seseorang. Menurut kedua pakar tersebut, karir merupakan persepsi pribadi sikap dan perilaku seseorang yang terkait dengan aktivitas dan pengalaman pekerjaan dalam rentang hidup dan tujuan seseorang di masa yang akan datang. Menurut Marwansyah, (2010) karir adalah pola aktivitas dan pengalaman yang terkait dengan pekerjaan (misalnya, posisi jabatan, tugas-tugas dalam jabatan, keputusan, dan penafsiran subyektif tentang peristiwa-peristiwa yang terkait dengan pekerjaan) sepanjang kehidupan pekerjaan seseorang. Pengembangan karir telah didefinisikan oleh beberapa ahli, diantaranya yaitu:

Davis \& Werther bependapat bahwa pengembangan karir (career development) adalah kegiatan-kegiatan pengembangan diriyang ditempuh oleh seseorang untuk mewujudkan rencana karir pribadinya (dalam Marwansyah, 2010). Menurut Jackson \& Vitberg, pengembangan karir adalah sebuah pendekatan formal yang dilakukan organisasi untuk memastikan bahwa orang dengan kualifikasi dan pengalaman yang tepat akan tersedia pada saat dibutuhkan (dalam Marwansyah, 2010).

Berdasarkan pengertian di atas, pengembangan karir merupakan usaha yang terorganisasi dan terencana yang terdiri atas aktivitas atau proses yang terstruktur yang menghasilkan timbal balik usaha perencanaan karir antara pegawai dan organisasi. Di dalam sistem pengembangan karir, pegawai bertanggung jawab terhadap perencanaan karir, sedangkan organisasi bertanggung jawab terhadap manajemen karir 


\section{Loyalitas Karyawan \\ Definisi Loyalitas}

Wicaksono (2013:48) menyatakan loyalitas adalah setia pada sesuatu dengan rasa cinta, sehingga dengan rasa loyalitas yang tinggi sesorang merasa tidak perlu untuk mendapatkan imbalan dalam melakukan sesuatu untuk oranglain / perusahaan tempat dia meletakan loyalitasnya. Menurut Hasibuan (2011:95), Kesetiaan dicerminkan oleh kesediaan karyawan menjaga dan membela organisasi di dalam maupun di luarpekerjaan dari rongrongan orang yang tidak bertanggung jawab. Semakin tinggi loyalitas para karyawan di suatu organisasi, makasemakin mudah bagi organisasi itu untuk mencapai tujuan-tujuan organisasi yang telah ditetapkan sebelumnya oleh pemilik organisasi. Begitu pula sebaliknya, bagi organisasi yang loyalitas para karyawannya rendah, maka semakin sulit bagi organisasi tersebut untuk mencapai tujuan-tujuan organisasinya yang telah ditetapkan sebelumnya oleh para pemilik organisasi.

Berdasarkan teori pendapat ahli diatas, dapat ditarik kesimpulannya bahwa loyalitas karyawan merupakan kesetiaan karyawan untuk memberikan kontribusi melakukan akivitas pekerjaan terhadap perusahaan karyawan mengharapkan imbalan atas kesetiaan yang sudah diberikan demi kemajuan organiasasi.

\section{Kerangka Pemikiran}

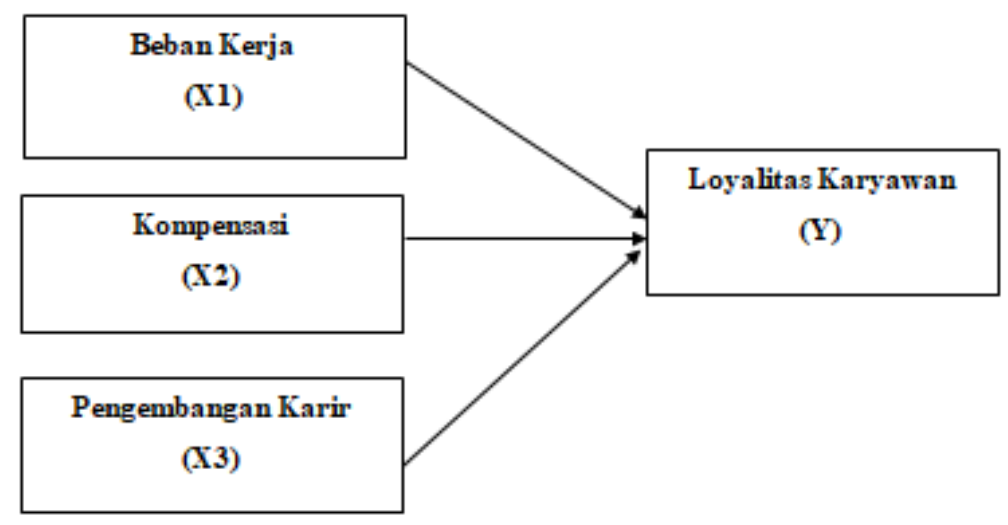

Gambar 1. Rerangka Konseptual

\section{METODE}

Proses penelitian ini diawali dengan kegiatan mengidentifikaasi permasalahan di tempat yang akan digunakan sebagai lokasi penelitian, perumusan masalah yang teridentifikasi, pengumpulan dasar teori yang memperkuat landasan dalam variabel, penyusunan metode dalam pengumpulan data, penyusunan instrumen, hingga penentuan teknik pengujian statistik yang dipergunakan. Pada proses ini dibutuhkan waktu penelitian dari bulan Juli sd Agustus 2020 hingga saat ini. Penelitian dilakukan di PT ABC.

\section{HASIL DAN PEMBAHASAN}

\section{Hasil Uji Regresi Linier Berganda}

Tabel 1. Hasil Uji Regresi Linier Berganda

\begin{tabular}{|c|c|c|c|c|c|}
\hline \multirow[b]{2}{*}{ Model } & \multicolumn{2}{|c|}{ Unstandardized Coefficients } & $\begin{array}{l}\text { Standardized } \\
\text { Coefficients }\end{array}$ & \multirow[b]{2}{*}{$\mathrm{T}$} & \multirow[b]{2}{*}{ Sig. } \\
\hline & $\mathrm{B}$ & Std. Error & Beta & & \\
\hline 1 (Constant) & 4,782 & 5,791 & &, 826 & ,411 \\
\hline Beban Kerja & ,101 &, 062 & ,101 & 1,617 &, 110 \\
\hline Kompensasi & ,314 & ,098 & ,269 & 3,199 &, 002 \\
\hline
\end{tabular}




\begin{tabular}{llllll}
\hline Pengemabangan Karir &, 865 &, 111 &, 648 & 7,796 &, 000 \\
\hline
\end{tabular}

Dependent Variable: Loyalitas Karyawan

Sumber: Hasil Pengolahan Data SPSS23

Berdasarkan hasil olah data dengan menggunakan SPSS23 pada Dari tabel diatas dapat diperoleh rumusan persamaan regresi linier berganda untuk variabel independen (Beban Kerja, Kompensasi, Pengembangan Karir) terhadap variabel dependen (Loyalitas Karyawan) sebagai berikut :

$$
\begin{aligned}
& \mathrm{Y}=\mathrm{a}+\mathrm{b} 1 \mathrm{X} 1+\mathrm{b} 2 \mathrm{X} 2+\mathrm{b} 3 \mathrm{X} 3+\mathrm{e} \\
& \mathrm{Y}=4,782+0,101 \mathrm{X} 1+0,314 \times 2+0,865 \times 3+\mathrm{e}
\end{aligned}
$$

Dari persamaan matematis regresi linier berganda tersebut dapat disimpulkan sebagai berikut:

a. Konstanta sebesar 4,782 merupakan perpotongan garis regresi dengan sumbu $\mathrm{Y}$ yang menunjukkan Loyalitas Karyawan PT. ABC ketika variabel bebasnya, yaitu Beban Kerja (X1), Kompensasi (X2) dan Pengembangan Karir (X3) sama dengan nol (0).

b. Variabel beban Kerja (X1) memiliki koefisien regresi positif, artinya bahwa apabila variabel Beban Kerja (X1) meningkat sebesar satu satuan maka Loyalitas Karyawan PT. ABC akan mengalami peningkatan sebesar nilai koefisien regresinya yaitu 0,101 dengan asumsi variabel bebas lainnya tetap.

c. Variabel Kompensasi (X2) memiliki koefisien regresi positif, artinya bahwa apabila variabel Kompensasi (X2) meningkat sebesar satu satuan maka Loyalitas Karyawan PT. ABC akan mengalami kenaikan sebesar nilai koefisien regresinya yaitu 0,314 dengan asumsi variabel bebas lainnya tetap.

d. Variabel Pengembanagan Karir (X3) memiliki koefisien regresi positif, artinya bahwa apabila variabel Pengembanagan Karir (X3) meningkat sebesar satu satuan maka Loyalitas Karyawan PT. ABC akan mengalami kenaikan sebesar nilai koefisien regresinya yaitu 0,865 dengan asumsi variabel bebas lainnya tetap.

\section{Hasil Uji Hipotesis \\ Uji Koefisien Determinasi $\left(R^{2}\right)$}

Koefisien determinasi ini digunakan untuk mengatahui seberapa besar variabel-variabel bebas memiliki pengaruh terhadap variabel terikatnya. Nilai koefisien determinasi digunakan adjusted R square. Dapat dilihat pada tabel berikut ini:

Tabel 2. Hasil Uji Koefisien Determinasi (R2)

\begin{tabular}{clllll}
\hline Model & $\mathrm{R}$ & R Square & $\begin{array}{l}\text { Adjusted } \\
\text { Square }\end{array}$ & $\begin{array}{l}\text { Std. Error of Durbin Waston } \\
\text { the Estimate }\end{array}$ \\
\hline 1 &, $846^{\mathrm{a}}$ &, 716 &, 7055 &, 7731 &, 878 \\
\hline
\end{tabular}

Predictors : (Constant), BK, K, PK

Dependent Variable: LK

Sumber: Hasil Pengolahan Data SPSS23

Berdasarkan tabel 2 diketahui hasil koefisien determinasi (adjusted $\mathrm{R}^{2}$ ) sebesar 0,705 yang artinya 70,5\% yang berarti kontribusi Loyalitas Karyawan dapat dijelaskan oleh ketiga variabel independen yaitu Beban Kerja, Kompensasi dan Pengembanagan Karir. Jadi selebihnya sebesar 29,5\% dijelaskan oleh variable-variabel lain yang tidak diteliti dalam penelitian ini.

\section{Uji Ketepatan Model (Uji Statistik F)}

Uji statistik F menunjukkan apakah variabel independen yang dimaksud dalam model mempunyai pengaruh secara bersama-sama terhadap variabel dependennya. Hasil pengujian statistik F dapat dilihat pada tabel 3 berikut: 
JBEMK | Volume 1, Issue 1 (2021) | 36-45

Tabel 3. Hasil Uji Ketepatan Model (Uji Statistik F)

\begin{tabular}{|c|c|c|c|c|c|c|}
\hline \multicolumn{7}{|c|}{ ANOVA $^{\mathrm{a}}$} \\
\hline Mode & & $\begin{array}{l}\text { Sum of } \\
\text { Squares }\end{array}$ & Df & $\begin{array}{l}\text { Mean } \\
\text { Square }\end{array}$ & $\mathrm{F}$ & Sig. \\
\hline \multirow[t]{3}{*}{1} & $\begin{array}{l}\text { Regressio } \\
n\end{array}$ & 6392,646 & 3 & 2130,882 & 63,937 &, $000^{\mathrm{b}}$ \\
\hline & Residual & 2532,904 & 76 & 33,328 & & \\
\hline & Total & 8925,550 & 79 & & & \\
\hline \multicolumn{7}{|c|}{ a. Dependent Variable: LK } \\
\hline \multicolumn{7}{|c|}{ b. Predictors: (Constant), BK, K, PK } \\
\hline
\end{tabular}

Berdasarkan Tabel 3 dapat dilihat nilai probabilitas sig 0,000 itu berarti nilai probabilitas lebih kecil dari 0,05 maka model diterima, sehingga dapat disimpulkan bahwa Beban Kerja, Kompensasi dan Pengembangan Karir secara bersama-sama berpengaruh terhadap Loyalitas Karyawan.

\section{Uji Ketepatan Signifikansi Parsial (Uji t)}

Uji Statistik t pada dasarnya menunjukkan seberapa jauh pengaruh satu variabel penjelas atau independen secara individual dalam menerangkan variasi variabel dependen. Pengambilan keputusan dapat dilakukan dengan melihat probabilitas. Jika probabilitas/signifikansi $>0,05$ maka Ho diterima dan Ha ditolak dan jika probabilitas/signifikansi $<0,05$ maka Ho ditolak dan Ha diterima.

Tabel 4. Hasil Uji Ketepatan Signifikansi Parsial (Uji t)

\begin{tabular}{|c|c|c|c|c|c|c|}
\hline \multirow{2}{*}{\multicolumn{2}{|c|}{ Model }} & \multicolumn{2}{|c|}{$\begin{array}{l}\text { Unstandardized } \\
\text { Coefficients }\end{array}$} & \multirow{2}{*}{$\begin{array}{l}\text { Standardized } \\
\text { Coefficients } \\
\text { Beta }\end{array}$} & \multirow[b]{2}{*}{$\mathrm{T}$} & \multirow[b]{2}{*}{ Sig. } \\
\hline & & $\mathrm{B}$ & Std. Error & & & \\
\hline \multirow[t]{4}{*}{1} & (Constant) & 4,782 & 5,791 & &, 826 &, 411 \\
\hline & Beban Kerja &, 101 &, 062 & ,101 & 1,617 &, 110 \\
\hline & Kompensasi & ,314 & ,098 & ,269 & 3,199 &, 002 \\
\hline & Pengembangan Karir &, 865 & ,111 & ,648 & 7,796 &, 000 \\
\hline
\end{tabular}

a. Dependent Variable: LK

Sumber: Hasil pengolahan data SPSS23

Dari tabel diatas dapat ditarik kesimpulan sebagai berikut:

a. Uji Hipotesis Beban Kerja Terhadap Loyalitas Karyawan

Berdasarkan tabel 4.23 probabilitas sig beban kerja sebesar 0,110 lebih besar dari 0,05, sehingga Ho diterima dan Ha ditolak, maka dapat dinyatakan secara parsial (X1) berpengaruh tidak signifikan terhadap Loyalitas Karyawan (Y).

b. Uji Hipotesis Kompensasi Terhadap Loyalitas Karyawan

Berdasarkan tabel 4.23 probabilitas sig Kompensasi sebesar 0,002 lebih kecil dari 0,05, sehingga Ho ditolak dan Ha diterima, maka dapat dinyatakan secara parsial kompensasi (X2) berpengaruh signifikan terhadap loyalitas karyawan (Y).

c. Uji Hipotesis Pengaruh Pengembangn Karir Terhadap Kinerja Karyawan

Berdasarkan tabel 4.23 probabilitas sig disiplin kerja sebesar 0,000 lebih kecil dari 0,05 sehingga Ho ditolak dan Ha diterima, maka dapat dinyatakan secara parsial Pengembangan Karir (X3) berpengaruh signifikan terhadap Loyalitas karyawan (Y).

\section{Pembahasan Hasil Penelitian}

\section{Pengaruh Beban Kerja Terhadap Loyalitas Karyawan}

Berdasarkan hasil perhitungan uji hipotesis statistika dapat disimpulkan bahwa variabel Beban kerja tidak berpengaruh terhadap Loyalitas Karyawan di PT. ABC. Hal ini disebabkan Beban Kerja bukan menjadi suatu hambatan dalam terbentuknya suatu loyalitas karyawan dalam bekerja karena hal tersebut sudah menjadi tanggung jawab dari masing-masing individual karyawan dan Karyawan PT. ABC mendapatkan tekanan dari pimpinan yang menyebabkan karyawan merasa cemas dalam menyelasikan pekerjaan. Selain itu, Kurangnya kerjasama antar individu karyawan yang menyebabkan loyalitas karyawan menurun. Hasil penelitian ini serupa 
dengan penelitian Indah Nurul Huda (2018) yang menyimpulkan bahwa beban kerja berpengaruh tidak signifikan terhadap loyalitas karyawan. Selain itu Hernika Rahadiwati (2013) menyimpulkan bahwa Stres Kerja, beban kerja berpengaruh tidak signifikan terhadap loyalitas kerja.

\section{Pengaruh Kompensasi Terhadap Loyalitas Karyawan}

Berdasarkan hasil perhitungan uji hipotesis statistika dapat disimpulkan bahwa variabel Kompensasi berpengaruh positif dan signifikan terhadap Loyalitas Karyawan di PT. ABC. Hal ini menunjukkan Kompensasi yang dimiliki oleh karyawan itu baik maka akan meningkatkan dan mempengaruhi Loyalitas Karyawan. Kurangnya kompensasi dan penghargaan yg diterima oleh Karyawan PT. ABC menyebabkan karyawan memiliki rasa keinginan tinggi untuk mendapatkan tunjangan - tunjangan lain di luar gaji pokok yg diterima. Dan Selain itu, Kurangnya akan kompensasi yg diterima, maka karyawan ingin memiliki penghasilan tambahan di luar perusahaan yang menyebabkan loyalitas itu menurun. Hasil penelitian ini didukung oleh penelitian Safitri (2015) yang menyatakan bahwa kompensasi memiliki pengaruh positif dengan loyalitas karyawan. Penelitian lain yang mendukung yaitu penelitian Pratama (2014), bahwa kompensasi memberikan pengaruh yang paling dominan terhadap loyalitas karyawan.

\section{Pengaruh Pengembangan karir Terhadap Loyalitas Karyawan}

Berdasarkan hasil perhitungan uji hipotesis statistika dapat disimpulkan bahwa variabel Pengembangan Karir berpengaruh positif dan signifikan terhadap Loyalitas Karyawan di PT. ABC. Kurangnya kepedulian perusahaan dalam memberikan peluang kesempatan karyawan dalam menggali kemampuan dan potensi diri dan kurangnya peningkatan karir yang diperoleh selama karyawan bekerja. Selain itu Karyawan memilki rasa ketidaksepakatan apabila setiap peningkatan karir dilakukan oleh perusahaan atas dasar harus memiliki status pendidikan yang tinggi. Sebagian besar karyawan banyak yang bekerja bertahun - tahun dan tidak memiliki status pendidikan yang tinggi namun karyawan sudah memiliki banyak pengalaman dan pengabdian dalam bekerja di PT. ABC. Hal ini sejalan dengan hasil penelitian yang dilakukan oleh Olivia Cornelia (2016) dimana Pengembangan Karir berpengaruh positif dansignifikan terhadap Loyalitas Karyawan.Selain itu serupa dengan penelitian oleh Atik Rahmawati (2013) yaitu Pengembangan karir sangat signifikan positif mempengaruhi loyalitas kerja.

\section{KESIMPLAN DAN SARAN}

\section{Kesimpulan}

Berdasarkan hasil penelitian dan pembahasan pada bab sebelumnya mengenai pengaruh Beban Kerja, Kompensasi dan Pengembangan Karir terhadap Loyalitas Karyawan di PT. ABC, maka kesimpulan dalam penelitian ini sebagai berikut:

1) Berdasarkan hasil uji parsial (Uji t) Beban Kerja tidak berpengaruh terhadap Loyalitas Karyawan. Artinya bahwa beban kerja tidak menjadi tekanan dan beban besar yang diterima oleh karyawan PT. ABC.

2) Berdasarkan hasil uji parsial (Uji t) kompensasi berpengaruh terhadap Loyalitas Karyawan. Artinya bahwa karyawan mengharapkan adanya program kompensasi yang semakin membaik dan mendapatkan tunjangan dan penghargaan tambahan lainnya untuk karyawan yang telah lama bekerja di PT. ABC sehingga loyalitas karyawan dapat meningkat.

3) Berdasarkan hasil uji sparsial (Uji t) Pengemabangan Karir berpengaruh signifikan terhadap Loyalitas Karyawan. Artinya bahwa karyawan mengharapkan adanya peluang karir dan program pengembangan karir, selain itu karyawan memiliki kesempatan karir tanpa perlu ada prasyarat status maupun pendidikan, sehingga loyalitas karyawan akan meningkat di PT. ABC.

\section{Saran}

Berdasarkan hasil kesimpulan diatas, maka dapat diberikan saran-saran sebagai berikut:

1) Saran untuk PT. ABC

a. PT. ABC perlu membuat kebijakan baru mengenai sistem kompensasi yaitu agar karyawan tidak memiliki keinginan mengahasilkan pekerjaan tambahan di luar pekerjaan dan karyawan memiliki rasa senang agar penghasilan sesuai dengan kewajibannya dalam bekerja dengan hal itu bertujuan untuk meningkatkan loyalitas karyawan. 
b. PT. ABC perlu membuat kebijakan baru untuk membuat program pengembangan karir yang lebih baik agar karyawan dapat memiliki peluang jabatan untuk Operasioanal Manager, Area Manajer, Supervisor dan Store Manager tanpa perlu memberikan prasyarat status dan pendidikan minimal Starta 1selain itu memberikan kesempatan karyawan untuk mendapatkan jabatan dalam waktu 2-5 tahun untuk proses kenaikan jabatan tersebut agar loyalitas karyawan meningkat.

2) Saran untuk Penelitian Selanjutnya

Saran untuk penelitian selanjutnya agar bisa meneliti lebih lanjut dengan objek perusahaan yang berbeda, dengan mengembangkan kembali variabel dan indikator yang belum digunakan dalam penelitian ini dan peneliti disarankan memilih peruasahaan yang bergerak dibidang lain yang bersedia memberikan informasi yang lebih kepada peneliti untuk riset penelitian agar mempermudah mendapatkan data yang dibutuhkan oleh peneliti.

\section{REFERENCES}

Heryati, Agustina, 2012.Pengaruh beban kerja dan kompensasi terhadap loyalitas karyawan di Department Koperasi PT. Pupuk Sriwidjaja Palembang (2012) ISSN: 2540-816X Volume 1 Nomor 2 Edisi Agustus 2016

Soleman, Aminah. 2011, Analisis Beban Kerja Ditinjau Dari Faktor Usia Dengan sPendekatan. Recommended Weight Limit (Studi Kasus Mahasiswa Upatti Poka). Jurnal Arika, Vol. 05. No. 2 (Agustus 2011). ISSN: 1978-1105. Volume 1 Nomor 2 Edisi Agustus 2016 ISSN : 2540-816X JURNAL Ecoment Global 75

Corenelia, Olivia. 2016, Pengaruh Pengembangan Karir terhadap Loyalitas karyawan PT ABC (2016)

Safitri, Rahmadani. 2015. Pengaruh Kompensasi terhadap loyalitas karyawan PT. Putera Lautan Kumala Lines Samarinda. jurnal Administrasi Bisnis,Universitas Mulawarma.

Maharani, Ni Made at al. 2013,Pengaruh Insentif terhadap Loyalitas Karyawan Studi pada Karyawan Tetap PT. SIER (Persero) Surabaya, Universitas Brawijaya. Jurnal Administrasi Bisnis VOL 2, NO 2.

Juliani, Retno Djohar. 2015. Pengaruh Kompensasi terhadap Loyalitas Karyawan, Jurnal Ekonomi dan Bisnis Universitas Pandanaran Semarang, Vol No 2.

Dessler, Gary. 2015. Human Resource Management (14 29th edition). Jakarta :Salemba Empat.

Fajariani, Ni Putu Eka dan Surya, I.B.Ketut. 2015. Pengaruh pengalaman kerja dan kepemimpinan transformation terhadap loyalitas karyawan. E-Jurnal Manajemen Unud, Vol. 4, No. 4, 2015: 930-942.

Ghozali, Imam. 2011. Aplikasi Analisis Multivariate Dengan Program SPSS 19 (edisi kelima) Semarang : Universitas Diponegoro.

Hasibuan, S.P. Malayu. 2010. Manajemen Sumber Daya Manusia, edisi revisi. Jakarta : PT Bumi Aksara.

Adil Kurnia, 2010. Workshop Workload Analysis Beban Kerja : Surabaya

Ghozali, Imam, 2013. Aplikasi Analisis Multivariate Dengan prograam IBM SPSS 19 (Edisi Ke-5.) Universitas Dipenogoro : Semarang.

Sugiyono. 2010. Metode Penelitian Administratif. Bandung: Alfabeta.

Sugiyono. 2011. Metode Penelitian Administratif. Bandung: Alfabeta.

Sugiyono. 2013. Metode Penelitian Pendidikan Pendekatan Kuantitatif, Kualitatif, dan R\&D. Bandung: Alfabeta

Sugiyono. 2015. Metode Penelitian Pendidikan Pendekatan Kuantitatif, Kualitatif, dan R\&D. Bandung: Alfabeta

Bayu, Wicaksono. 2012. Pengaruh Kepuasan Kerja, Loyalitas Karyawan, Dan Komitmen Organisasi Terhadap Kinerja Karyawan (Studi Kasus Pada PT Vision land Bagian Packing). Program Studi Manajemen Fakultas Ekonomi Universitas Stikubank

Tommy, dkk.2010. Manajemen Tenaga Kerja Indonesia.Jakarta : PT. Bumi Aksara

Rivai, Veithzal dan Ella Jauvani Sagala, 2013, Manajemen Sumber Daya Manusia untuk Perusahaan :Dari Teori ke Praktik, Edisi Kedua. Cetakan Kelima. PT.Rajagrafindo Persada, Jakarta.

Hasibuan, Malayu S.P., 2011. "Manajemen Sumber Daya Manusia". Bumi Aksara, Jakarta

Hasibuan, Malayu. 2012. "Manajemen Sumber Daya manusia". Jakarta: PT Bumi Aksara.

Hasibuan, Malayu. 2013."Manajemen Sumber Daya Manusia”. Cetakan Ketujuh Belas. Jakarta. Bumi Aksara. Marwansyah. (2010). "Manajemen Sumber Daya Manusia” Edisi Kedua. Bandung:Alfabeta.

Angga Rahyu Shaputra dan Susi Hendriani. 2015. Pengaruh Kompetensi,Komitmen Dan Pengembangan Karir Terhadap Kinerja Karyawan Pt.Bank Rakyat Indonesia (Persero) Kantor Wilayah Pekanbaru Jurnal Tepak Manajemen Bisnis Vol VII No 1 Januari 2015 
Donni Junni Priansa 2014, Perencanaan \& Pengembangan SDM, Penerbit Bandung: Alfabeta

Hartatik, Indah Puji. 2014. Buku Praktis Mengembangkan SDM, Jogjakarta Laksana.

Hermawan, I Ketut A dan Gede Riana. (2014), "Analisis Faktor-Faktor Yang Menentukan Loyalitas Karyawan padaPT. Inti Buana Permai Denpasar Bali”. Vol.3 No.3, e-jurnal manajemen, Hal 624-643.

Huda, Nurul Huda. 2018, Beban Kerja dan Loyalitas Karyawan Pada Generasi Y di PT X Yogyakarta (2018)

Rahadiwati, Hernika 2013, Hubungan Antara Stres Kerja Dengan Loyalitas karyawan Pada Karyawan CV. Sinar Abadi (2013)

Pratama, Aditia, Suryoko, Sri Dan Widiartanto 2014, Pengaruh Kompensasi, Lingkungan Kerja, Dan Beban Kerja Terhadap Loyalitas Karyawan Melalui Kepuasan Kerja Pada Karyawan PT Kawasan Berikat Nusantara Persero Jakarta (2014)

Rahmawati, Atik 2013, Hubungan Antar Persepsi Terhadap Pengembangan Karir Karyawan Dengan Loyalitas Kerja CV. Sinar Abadi (2013)

Dessler, Gary, 2011.Manajemen sumber daya manusia. Penerbit Indeks, Jakarta

Bambang Wahyudi. (2010). Manajemen Sumber Daya Manusia. Jakarta:Sulita

Robbins. Stephen. P., Coulter. Mary. (2012). Management. Eleventh Edition. Jakarta: England.

Gaol, CHR. Jimmy L, 2014. A to Z Human Capital (Manajemen Sumber Daya Manusia) Konsep, Teori, dan Pengembangan dalam Konteks Organisasi Publik dan Bisnis, PT. Gramedia Widiasarana, Jakarta.

Yani, M, 2012, Manajemen Sumber Daya Manusia, Mitra Wacana Media, Jakarta

Samsudin, Sadili.2010. Manajemen Sumber Daya Manusia. Bandung : Pustaka Setia

Danang, Sunyoto. 2012. Manajemen Sumber Daya Manusia. Jakarta: PT Buku Seru.

Arika. (2011). Jurnal artikel Analisis Beban Kerja Ditinjau dari Faktor Usia Dengan Pendekatan Recommended Weight Limit.

Arikunto, Suharsimi. (2010). Prosedur Penelitian : Suatu Pendekatan Praktik. Edisi Revisi. Jakarta: Rineka Cipta

Nursalam. (2011). Konsep dan penerapan metodologi penelitian ilmu keperawatan. Jakarta : Salemba Medika

Muskamal. 2010. Analisis Beban Kerja Organisasi Pemerintah Daerah. PKP2A II. LAN Makassar.

Tarwaka. 2011. Ergonomi Industri, Dasar-Dasar Pengetahuan Ergonomi dan Aplikasi Di Tempat Kerja. Surakarta: Harapan Press.

Suwanto. 2011. Manajemen Sumber Daya Manusia dalam Organisasi Publik dan Bisnis. Alfabeta. Bandung

Ivancevich, John M. (2013).Human Resource Management, Eleventh Edition.New York: McGraw-Hill.

SondangP. Siagian. 2011. Manajemen Sumber Daya Manusia. Jakarta: Bumi Aksara. Jakarta

Hadi, Nor. 2013. Pasar Modal. Yogyakarta: Graha Ilmu

Siswanto. (2010). Pengantar Manajemen. -Cet.6. Jakarta: Bumi Aksara

Soegandhi, Vannecia. M dkk. (2013). Pengaruh Kepuasan Kerja dan Loyalitas Kerja Terhadap Organizational Citizenship Behavior Pada Karyawan PT Surya Timur Sakti Jatim. Volume 1. Nomor 1. Program Manajemen Bisnis, Program Studi Manajemen. Universitas Kristen Petra.

Lai, Jennifer. Marrone, Mauricio "Implementation of a Curriculum Management

Tool: Challenges Faced by a Large Australian University" Asian Social Science No. 8 , 14 November 2012.

Primala, D. A. (2017). Mengapa Kesehatan Mental di Tempat Kerja Butuh Perhatian?. Diakses $30 \quad$ Juli 2018 https://pijarpsikologi.org/kesehatan-mental-di-tempat-kerja/

Martiwi, Rukmi Tien (2012) Faktor-Faktor Penentu Yang Mempengaruhi Loyalitas Kerja Karyawan (Studi Kasus Pada Bank Danamon Sudirman Solo). Thesis thesis, Universitas Muhammadiyah Surakrta.

Misbahudin, Iqbal Hasan, (2013), Analisis Data Penelitian Dengan Statistik, Jakarta, Bumi Aksara.

Upasana, K., M. (2015). Influence of Compensation on Employee Loyalty to Organization. Asian Journal of Multidiciplinary Studies, 03(02)

HaniHandoko, 2010, Manajemen Personalia \& Sumberdaya Manusia, Edisikedua, BPFE UGM Yogyakarta

Sugiyono, 2013, Metodelogi Penelitian Kuantitatif, Kualitatif Dan R\&D. (Bandung: ALFABETA)

Sugiyono. 2014.Metode Penelitian Pendidikan Pendekatan Kuantitatif,Kualitatif Dan R\&D.Bandung: Alfabeta

Sekaran, uma dan Roger Bougie.(2010). Edisi 5, Research Method For Business: A Skill Building Approach. John Wiley@ Sons, New York

P.Joko Subagyo. 2011.Metodologi Penelitian Dalam Teori Dan Praktek. Jakarta : Aneka Cipta.

Hartono, Jogiyanto. (2011). Metodologi Penelitian Bisnis: Salah Kaprah dan Pengalaman-pengalaman.BPFE. Yogyakarta

Masari, Kartikadan Kezia Kurniawati Nursalin, (2011). Pengaruh Customer Relationship Management Terhadap Loyalitas Pelanggan pada PT. BCA Tbk. Fokus Ekonomi, Vol 10, No 3 
JBEMK | Volume 1, Issue 1 (2021) | 36-45

Jusuf, Husain. 2010. Tingkatkan Loyalitas Guna Peningkatan Prestasi Kerja dan Karir.

Agustini, 2010.Manajemen Sumber Daya Manusia Lanjut, Jakarta : Penerbit Medenatera 